\begin{tabular}{c}
\hline KEMAS 13 (3) (2018) 396-403 \\
Jurnal Kesehatan Masyarakat
\end{tabular}

\title{
EFFECTIVENESS OF VIRGIN COCONUT OIL AND VIRGIN OLIVE OIL ON PERINEAL LACERATION
}

\author{
Nor Asiyah $^{1}$, Indah Risnawati ${ }^{1}$, Fania Nurul Khoirunnisa ${ }^{1}$ \\ ${ }^{1}$ STIKES Muhammadiyah Kudus, Kudus, Indonesia
}

\begin{tabular}{l} 
Article Info \\
\hline Article History: \\
Submitted September 2017 \\
Accepted February 2017 \\
Published March 2018 \\
\hline Keywords: \\
Laceration of the peri- \\
neum, Virgin Coconut \\
Oil, Virgin Olive Oil \\
\hline DOI \\
https://doi.org/10.15294/ \\
kemas.v13i3.11076
\end{tabular}

\begin{abstract}
Perineal massage is one of the way to reduce maternal morbidity and reduce the risk of bleeding caused by laceration of the perineum. Not only Virgin Olive Oil, but also Virgin Coconut Oil becomes the alternative thing that easily absorbed by the skin. This study aims to examine the effect of Virgin Coconut Oil and Virgin Olive Oil on perineal massage on the degree of perineal laceration. This research was Quasi experimental designs, with the subjects were pregnant women with gestational age $\geq 34-35$ weeks. The data used the Mann-Whitney test and tested 2 proportions to assess the effectiveness of the essential oils used. The result showed that there was influence of perineal massage with perineal laceration $(\mathrm{p}<0,05)$. Therefore, there is influence of $\mathrm{VCO}$ and $\mathrm{VOO}$ on perineal massage against the perineal laceration event. Further research is needed to assess the determinants of perineal laceration with different variables or interventions.
\end{abstract}

\section{Introduction}

International community has committed to decrease Maternal Mortality Rate (MMR). The mortality and morbidity on pregnant woman and postpartum mother are quite high particularly in developed countries. In 2005 the mortality of giving birth mother in many countries reached 536/100,000 Living Birth. Indonesia Demographic and Health Survey in 2012 recorded the MMR in Indonesia was 359 per 100,000 living birth. It still far enough from Sustainable Development Goals (SDG's) target which is 70 per 100,000 living birth in 2030. The largest cause of MMR in Indonesia is bleeding (40-60\%) and 57,93\% of MMR takes time on postpartum. Postpartum bleeding case is caused by atonia uteri (50\%-60\%), retensio placenta $(16 \%-17 \%)$, left over placenta $(23 \%$ -
$24 \%)$, perineum laceration (4\%-5\%) and blood abnormality $(0,5 \%-0,8 \%)$ ( Ministry of Health, 2012, (Kemenkes, 2012, Gamelia et al., 2016, Mahmudah et al., 2011, Kurniawan et al., 2017, Kurniawan and Maulina, 2015).

Perineum laceration percentage takes place on fourth rank of postpartum bleeding cause. If does not well treated, the perineum rupture can lead to complication like bleeding, hematoma, fistula, infection, anus incontinence, urin incontinence and the worst is fistula formation (Mukhoirotin and Khusniah, 2010, Puri and Leppert, 2011, Prawitasari et al., 2015, Bulchandani et al., 2015).

Perineum laceration can reach the vagina, servics, uterus and perineum. Perineum is the most vulnerable organ that can ruptured along the partum proces, beside the position

\footnotetext{
Correspondence Address:

STIKES Muhammadiyah Kudus, Kudus, Indonesia

Email : norasiyah@stikesmuhkudus.ac.id
} 
that located between vagina and rectum, the perineum structure consist of muscles and mucosa that vulnurable to be ruptured or lacerated . (Anggraini, 2016, Leeman et al., 2003).

Ruptured perineum can occur spontaneously or due to episiotomi. This is caused by several factors. The main one is perineum condition. The tense and stiff perineum can not take dilatation process completely. One of the treatment to prevent ruptured perineum is by perineal massage (Anggraini, 2016, Beckmann MM and Stock OM, 2013).

Perineal message is one media to reduce MMR and bleeding risk caused by ruptured perineum. Perineal message also as a support to government program in national strategic plan Making Pregnancy Safer (MPS), where the effort to solve health problem by accentuating promotive and preventive aspect (Siswosudarmo, 2008, American College of Nurse-Midwives, 2005).

Perineal message is related with the reduction of traumatic injury require suture (4 experiments, 2480 women, RR 0,91, 95\% CI 0,86-0,96). Perineal message is safe and effective when it is applied routinely with proper technique. The message is supported with the application of lubricant (perineal cream) or essential oil like zaitun oil, wheat oil or other natural oil (Attarha et al., 2009, Seehusen and Raleigh, 2014, Stamp et al., 2001, Fernando et al., 2015).

Olive oil is used as primary option in perineal massage as it rich of oleic acid and polyphenols that could improve perineum elastisity. Olive oil with $80 \%$ oleat acid can shabby the skin and preserve elasticity from injury and inflammation. General inflammation indictor is C-reactive protein or CRP in blood. Olive oil has beneficial effect on CRP reduction. Nomikos (2010) in a research stated that massage with olive oil help to alleviate muscle fatigue, eliminate lactacic acid and prevent sport injury (Attarha et al., 2009, Dahl et al., 2016, Nomikos et al., 2010)

Beside olive oil, other alternative is coconut oil as one of various natural oil in Indonesia. Coconut oil can preserve health and prevent atherosclerosis, can be anti fungus and anti virus for containing, particularly, lauric acid which reach 50\% (Nomikos et al., 2010, Attarha et al., 2009, Vala and Kapadiya, 2014).

Verallo (2008) research mentioned that Staphylococcus Aureus colony on dermatitis patient skin, after intervention only 5\% VCO subject still positive compare to $50 \%$ VOO subject. Nevin (2008) said that a wound treated with VCO is cured faster, colagen tissue increase, fibroblast proliferation and neovascularitation on the wound (Kalichman, 2008, Prismania and Wagiyo, 2013, Nevin and T.Rajamohan, 2008, Verallo et al., 2008).

$\mathrm{VCO}$ is rich of vitamin E playing role in cell containment mechanism in cell's organ, significantly improve antioxidant enzyme activity, fibroblast proliferation and neovascularitation. Coconut oil is save to be smeared on skin even on wounded one with minimum risk of allergy. Coconut oil is potentially used to improve elastisity of perineum skin and expedite blood circulation thus in childbirth process the perineum able to follow dilatation process completely and reduce the risk of perineum rupture (Prismania and Wagiyo, 2013, Nevin and T.Rajamohan, 2008, Fatonah et al., 2013).

There has not been further research to study the benefit of coconut oil to perineal laceration degree. So researcher is interested to study the effectivity of $\mathrm{VCO}$ and VOO application in perineal massage to perineal laceration degree. It is important to be informed and applied that perineal massage with coconut or olive oil application is one of nonfarmacologic intervention to prevent perineum rupture. The objective of this research is to study the effect of VCO and VOO application on perineal massage to perineal laceration degree.

\section{Method}

The subject in this research is pregnant women with gestational age 34-35 weeks. The research location was on Kabupaten Kudus region Practising Midwife (Bidan Praktek Mandiri/BPM). The population in this research is all mother giving birth on Kabupaten Kudus region BPM. Sample in this research is divided into 2 groups, size of simple experiment sample with control with small sample 10 to 20 per group. First group contains 20 persons use VCO as lubricant in perineal massage, while 
second group contains 20 persons use VOO in perineal massage. The sample was taken by non randomize sampling with quota sampling method.

The design is Quasi experimental, where on this design the experiment is conducted without complete control. The subject is pregnant women with gestational age 34-35 weeks. The research location was on Kabupaten Kudus region BPM, aligned to inclusion criteria. The population in this research is all mother giving birth on Kabupaten Kudus region BPM (Dahlan, 2011)

Kind and source of the data are from primary and secondary data. Primary data is obtained through a checklist which are several written questions arranged to gain required information from respondent. While secondary data is obtained from medical record regarding the respondent and partograph to assest perineal laceration during birthing process.

The instrument of data collection is checklist and partograph sheet. The checklist is used to assest the application of perineal massage, two question regarding the application of perineal massage and the application of perineal massage table. Backward of partograph is used as observation tool on perineal laceration evaluation and episiotomy. Data collection was started from researcher gaves explaination regarding perineal massage, when the respondent approved the data collection then researcher would hand over an informed consent to be signed. The researcher asked respondent's identity and several data support. After the respondent signed the informed consent as inclusion criteria, the researcher then gave the example of perineal massage. Respondent can also watch it on video material or given leaflet. Then the respondent is given a checklist as monitoring sheet of perineal massage application that should be filled daily and would be collected after birth giving process was completed. The perineal massage was applied 4-6 weeks before giving birth with 3-5 minutes duration, once a day.

Then the researcher would follow the birth giving process from beginning to end and observed the perineal laceration degree. After data was collected the it will be tabulated into the data collection matrix (observation sheet) previously prepared, then be analyzed.

Analysis design used were Univariable Analysis which is purposed to descript the characteristic of each research varible by considering frequence distribution and percentage of each variable. The characteristics seen on this research were age, parity, weight of the borned baby. Also Bivariable Analysis to assest the effectivity of independent variable which are the application of coconut oil or olive oil on perineal massage to dependent variable perineal laceration. To calculate the statistic value, Man-Whitney test was used.

\section{Result and Discussion}

The research of Effectiveness of Virgin Coconut Oil (VCO) and Virgin Olive Oil (VOO) application on Perineal Massage to Perineal laceration was conducted on April until August 2017 and took place on Maternity House and Practising Midwife (Bidan Praktek Mandiri/ BPM) in Kabupaten Kudus Region. The intervention is perineal massage uses essential oil which are Virgin Coconut Oil (VCO) and Virgin Olive Oil (VOO) on pregnant women with gestational age $\geq 34$ weeks, then followed until the birth giving and assests the perineal laceration degree. The VCO was applied to the subject at Fatimah Maternity House address Jl.Agil Kusumadya gg. Sempalan Jati Kulon 3/3 Kabupaten Kudus and Nor Asiyah Practising Midwife address Desa Karangampel 4/3 Kaliwungu Kudus. Obtained subjects are 32 persons yet 10 persons were excluded. While VOO was applied to subject at Leny Mulyani Practising Midwife address Desa Besito 3/5 and Tri Handayani Practising Midwife address Desa Menawan 3/3 Kecamatan Gebog Kabupaten Kudus. Obtained subjects are 28 persons yet 9 persons were excluded.

On research subject data taken were as follows mother characteristics ( age, parity and birth weight), perineal massage based on essential oil applied and perineal laceration degree. The data obtained was analyzed by Mann-Whitney test and 2 proportion test to evaluat the effectiveness of used essential oil.

For age characteristic, most of the respondent are on health reproduction age range which is 20-35 years old 36 persons $(87,8 \%)$. On parity characteristic, most of the respondent is multiparous 25 persons (61\%) 
Table 1. Characteristics of the Subject

\begin{tabular}{|c|c|c|c|c|c|c|c|}
\hline \multirow[t]{3}{*}{ No } & \multirow[t]{3}{*}{ Characteristics } & \multicolumn{4}{|c|}{ Perineal massage } & \multicolumn{2}{|c|}{ Total } \\
\hline & & \multicolumn{2}{|c|}{$\mathrm{VCO}$} & \multicolumn{2}{|c|}{$\mathrm{VOO}$} & \multirow[b]{2}{*}{$\mathrm{n}$} & \multirow[b]{2}{*}{$\%$} \\
\hline & & $\mathrm{n}$ & $\%$ & $\mathrm{n}$ & $\%$ & & \\
\hline \multirow[t]{3}{*}{1.} & Age & & & & & & \\
\hline & High risk & 3 & 7,3 & 2 & 4,9 & 5 & 12,2 \\
\hline & Health Reproduction Age & 19 & 46,3 & 17 & 41,5 & 36 & 87,8 \\
\hline \multirow[t]{3}{*}{2.} & Parity & & & & & & \\
\hline & Primipare & 10 & 24,4 & 6 & 14,6 & 16 & 39 \\
\hline & Multiparous & 12 & 29,3 & 13 & 31,7 & 25 & 61 \\
\hline \multirow[t]{4}{*}{3.} & Birth weight & & & & & & \\
\hline & Low Birth Weight & 0 & 0 & 4 & 9,8 & 4 & 9,8 \\
\hline & Normal & 15 & 36,6 & 12 & 29,3 & 27 & 65,9 \\
\hline & High & 7 & 17,1 & 3 & 7,3 & 10 & 24,3 \\
\hline
\end{tabular}

Source : Primary Data

Table 2. Comparation of Perineal laceration on VCO and VOO Perineal Massage Group

\begin{tabular}{|c|c|c|c|c|c|}
\hline \multirow{3}{*}{ Variable } & \multicolumn{4}{|c|}{ Group } & \multirow{3}{*}{$\mathrm{p}$ Value } \\
\hline & \multirow{2}{*}{$\begin{array}{c}\mathrm{VCO} \\
(\mathrm{n}=22)\end{array}$} & \multicolumn{3}{|c|}{ VOO } & \\
\hline & & $\%$ & $(n=19)$ & $\%$ & \\
\hline \multicolumn{6}{|c|}{ Perineal laceration } \\
\hline Intake & 3 & 7.3 & 0 & 0 & \multirow{5}{*}{$0,011^{\star}$} \\
\hline Degree 1 & 5 & 12.2 & 6 & 14.6 & \\
\hline Degree 2 & 11 & 26.8 & 4 & 9.8 & \\
\hline Degree 3 & 3 & 7.3 & 9 & 22 & \\
\hline Total & 22 & 53.6 & 19 & 46.4 & \\
\hline
\end{tabular}

Remark : $\left.{ }^{\star}\right)$ Mann-Whitney test

while for birth weight mostly are normal (2.500-3.500 gram) 27 persons (65,9\%).

The comparison of perineal laceration degree analysis on perineal massage groups between VCO and VOO are on table 2.

From the table can be seen that most of the respondent experienced degree 2 perineal laceration which were 15 persons (36.6\%). Based on statistic test, for perineal laceration on both groups shows $\mathrm{p}$ value $=0.011(\mathrm{p}<0.05)$ thus there is significant result.

On statistic test result table obtained that there is effect of perineal massage to perineal laceration $(\mathrm{p}<0.5)$. The risk of perineal laceration on controlled group (VOO) is 0.69 time (95\% CI 0.38-0.96) compare to treated group (VCO). Thus can be concluded that there is an effect of VCO and VOO application on perineal massage to perineal laceration, yet from $\mathrm{RR}$ value $<1 \quad(0.69 ; 95 \% \mathrm{CI}=0.38-0.96)$ indicated that VCO does not more effective than VOO.

Test on first hypothesis based on Mannwhitney test for perineal laceration on both group showed $\mathrm{p}$ value $=0.011(\mathrm{p}<0.05)$. By then first hypothesis is accepted which mean there is effectiveness of coconut oil and olive oil to perineal laceration degree. Result of second hypothesis based on two proportion test (one side) indicated that $\mathrm{p}$ value $<0,05$. Thus can be concluded that there is effect of VCO and VOO application on perineal massage to perineal laceration, yet from RR value $<1 \quad(0.69 ; 95 \% \mathrm{CI}$ $=0,38-0.96$ ) can be seen that VCO does not more effective than VOO on perineal laceration, thus second hypothesis is rejected. 
Table 3. Effect of Perineal Massage with VCO and VOO to Perineal laceration

\begin{tabular}{|c|c|c|c|c|c|c|c|c|}
\hline \multirow[t]{2}{*}{ Group } & \multicolumn{4}{|c|}{ Perineal laceration } & \multicolumn{2}{|c|}{ Total } & \multirow[t]{2}{*}{ RR (IK 95\%) } & \multirow[t]{2}{*}{$\mathrm{p}$ value } \\
\hline & Tear & $\%$ & Intact & $\%$ & $\mathrm{n}$ & $\%$ & & \\
\hline VOO & 10 & 24,4 & 9 & 22 & 19 & 46.4 & & \\
\hline VCO & 19 & 46,3 & 3 & 7.3 & 22 & 53.6 & $0.69^{*}(0.38-0.96)$ & $0.021^{\star}$ \\
\hline Total & 29 & 70,7 & 12 & 29.3 & 41 & 100 & & \\
\hline
\end{tabular}

Based on mother age characteristic, most of respondents are in health reproduction age which is between 20 -35 years old 36 persons $(87.8 \%)$. Health reproduction age is a safe, ideal age for a woman to pregnant and deliver birth since on the age range, reproduction organs have optimally developed and well functioned. Below 20 years old, reproduction organs have not been completely functioned, thus in case of pregnancy and giving birth will be easier to get complication (Siswosudarmo, 2008).

On reproduction age more than 35 years old, all body organs includes reproduction ones have been decreased qualitatively and ability, these can also risk to complication and reproduction disorder. Like decreased ovum quality will increase risk of giving birth children with borned disability, weak uterus muscle contraction will cause long giving birth process resulting long parturition, obstructed parturition, abandoned parturition. All lead to infant brain damage as result of brain wound or hypoxia. Old age also affect to degradation of skin elasticity so that it will be easily damage or laceration also on birth way.

On parity characteristic, most of respondents are multiparous 25 persons (61\%). Parity is considered to be corelated with perineal laceration through perineal rupture or perineal laceration treatment. Perineal rupture occures on nearly all first birth giving. This is due to the birth way has never been passed through the infant head so the perineal muscles have not stretched (Endriani et al., 2013).

The flexibility of skin and muscle tissues can be improved by repeatedly conduct certain trainings. As well as perineal flexibility, that can increase on multiparous since for several times had been strecthed by the passing through infant. Thus the perineal muscle flexibility has occured well by then on multiparous case, the perineal laceration is lower compare to perineal laceration on nulliparous.

For new born baby weight, most were on normal range (2,500-3,500 gram) 27 persons (65.9\%). The risk of perineum laceration is occured on the birth giving with large baby weight. This is due to the higher the baby weight, the higher risk that perinieal laceration will happen since the perineum does not firm enough to resist the stretch from baby's head. Beside that, the new born baby that too big or born with weight over than 4000 grams will increase birth giving process risk such as the shoulder stucked, the baby is borned with breath disorder and sometime the baby got neck bone, shoulder and nerve trauma. These are due to large mass of the baby so that difficult to go through mother pelvis and causing perineal rupture on giving birth mother (Anggraini, 2016).

The size of weight of baby borned will stretch perineal muscle over the elasticity boundary to cause the perineum has extra wide laceration degree or even reach degree 4 (rupture totalis). The degree 4 laceration required complicated treatment to restore the condition to the original condition to avoid complication such as anemia due to many blood came out through perineal laceration and fistula rekto-vaginalis.

From research result obtained that moarst of the respondents experienced degree 2 perineal laceration which were 15 persons (36.6\%). A research in Canada on parturient nullipara, obtained that the perineal massage resulted the increase of intact perineum chance until $10 \%$. The stretch and massage have been promoted as a technique to relax the perineum, prevent perineal tear and reduce the episiotomi 
requirement. On perineum massage, the tissue will reach natural enwidement phase by phase so that the laceration and severity decreased, able to reduce the hurt and less compication on birth way (Stamp et al., 2001).

Based on RCT research conducted by Stamp on 2001 regarding perineal massage obtained that the opportunity to have intact perineum on nulliparous with perineal massage is $18 \%(63 / 353)$ with absolut risk 1.13 , RR: 0.88 (95\% CI 0.65-1.21), ( $\mathrm{p}<0.50)$ while on parturien multiparous the opportunity is $38 \%(135 / 355)$ with absolut risk 0.91, RR:1.10 (95\% CI 0.89-1.35), ( $>0.05)$. Perineal massage with lubricant is high potention in preventing perineal laceration. The work mechanism are vasodilatation, improve muscle relaxation, more blood supply and emerge pleasant feeling for the mother (Stamp et al., 2001, Zare et al., 2014).

On this research, based on statistical test on both group indicate that there is significant variation for perineal laceration $(\mathrm{p}<0.05)$. The intervention given to the subject is perineal massage with application of essential oil which is olive oil (VOO) and coconut oil (VCO). The VOO is rich of oleic acid and polyphenols that able to lubricate and improve the perineal elasticity. The human alergy level to this oil is very rare. The olive oil with oleat acid until $80 \%$ can shabby the skin and protect from injury or trauma. The massage treatment along with olive oil application help to reduce muscle fatique, remove lactacic acid and prevent wound.

Beside the olive oil, coconut oil (VCO) is another media for perineal massage. VCO has characteristic easy to be absorbed by skin surface even by intestinal wall, consider as safe to be applied on skin. It contains middle chain saturated fat acid that easy to penetrate the skin and preserve the flexibility and elasticity. Coconut oil has more benefit compare to other natural oil which is able to preserve the vein health, prevent atherosclerosis, anti fungus and anti virus as result of various containing particularly lauric acid that reach $50 \%$. From previous study, it is found that a wound smeared by VCO is cured faster, increased of colagen tissue and proliferation, fibroblast and neovascularisation.

From this research can be concluded that there is effect of perineal massage to perineal laceration $(\mathrm{p}<0,05)$. This is aligned with the research by Kalichman, 2008 in form of latest sistematic overview published on Database Cochrane, contains three controlled experiments randomly involved 2434 women. First research by Labrecque et. al. obtain that perineal massage during ante natal period is related with the reduction of perineal trauma incident with RR 0,91 (95\% CI 0,86-0,96). The second obtained that women practising perineal massage are tends not to have episiotomy with RR 0,85 (95\% CI 0,75-0,97), NNT 23 (13-111). And the third obtained same conclusion with RR 0,85 (95\% CI 0,74-0,97), NNT 20 (11110). The antenatal perineum massage reduce the possibility of perineal trauma particularly episiotomy (Kalichman, 2008, Gurol-Urganci et al., 2013)

From this research the risk of perineal laceration on control group which is $\mathrm{VOO}$ application is 0,69 kali $(95 \%$ CI $0,38-0,96$ ) compare ot treated group (VCO). By then can be concluded that there is effect from the application of VCO and VOO in perineal massage to perineal laceration, yet from the RR $<1(0,69 ; 95 \% \mathrm{CI}=0,38-0,96)$, proven that $\mathrm{VCO}$ does not more effective than VOO on perineal laceration. The olive oil has high antioxidant and has many biological function beneficial to health such as able to fend free radicals giving sufficient protection against peroxidation. Olive oil is related with high ulcers cure and provide higher resistance compare to non-steroid antiinflamation medicine for stomach ulcers. Some studies indicate that olive oil and coconut oil can be used to cure inflamation and autoimun, like rheumatoid arthritis (Elsayed et al., 2015)

In this research there is researcher limitatin in controlling related variables, like baby weight and birth giving process duration. Similar research was done on 2008 to study the effect of perineal massage with water solving lubricant. In that research alternative hypothesis is rejected with the results such as laceration degree while giving birth was found increase significantly when expulsive time more than 15 minutes $(\mathrm{OR}=1.12)$ and based on logistic regression analysis indicated that baby weight was larger related with perineal laceration degree $2(\mathrm{OR}=1,80 ; 95 \%$ CI $1,529-2,123)$. It 
was assumed that related clinical factor that can increase the trauma risk. From previous research result also found out that woman with obesity (BMI $\left.\geq 30 \mathrm{~kg} / \mathrm{m}^{2}\right)$ has perineum laceration degree 3 and $4(\mathrm{OR}=0.75 ; 95 \% \mathrm{CI}$ 0.58-0.98). Small sample size also consider affecting the result and the subjects were not selected randomly, thus the result can be biased and can't be generalized for other population (Araújo and Oliveira, 2008, Fahami et al., 2012, Albers et al., 2005, Garretto et al., 2016)

\section{Conclusion}

Based on statistic test, for perineal laceration on both group indicated that there is significant variation $(p<0,05)$. This research resulting there is effect of perineal massage on perineum laceration $(p<0,05)$. The risk of laceration perineum on control group which is $\mathrm{VOO}$ is 0.69 time ( $95 \%$ CI $0,38-0,96$ ) compare to treatment group (VCO). Thus can be concluded that there is effect of VCO and VOO application on perineal massage to perineal laceration, yet from the RR $<1 \quad(0,69$; $95 \% \mathrm{CI}=0,38-0,96)$ can be seen that aplication of VCO does not more effective than VOO in the relation with perineal laceration incident

\section{Reference}

Albers, L. L., Sedler, K. D., Bedrick, E. J., Teaf, D. \& Peralta, P. 2005. Midwifery Care Measures in the Second Stage of Labor and Reduction of Genital Tract Trauma at Birth: A Randomized Trial. J Midwifery Womens Health, 50 (5): 365-72.

AMerican College of Nurse-Midwives 2005. Perineal Massage in Pregnancy. Journal of Midwifery \& Women's Health, 61(1).

Anggraini, D. F. 2016. Hubungan Berat Bayi Dengan Robekan Perineum Pada Persalinan Fisiologis di RB Lilik Sidoarjo. Jurnal Ilmiah Kesehatan, 9 (1): 91-7.

Araújo, N. M. \& Oliveira, S. M. J. V. 2008. The Use Of Liquid Petroleum Jelly In The Prevention Of Perineal Lacerations During Birth. Rev Latino-am Enfermagem, 16 (3): 375-81.

Attarha, M., Vacillian, C., Torkestany, N. A., Heydary, T. \& Bayateyan, Y. 2009. Effect of Perineal Massage during Second Phase of Labor on Episiotomy and Laceration Rates among Nulliparous women Midwifery. journal of Hayat, 15 (2).

Beckmann Mm \& Stock Om. 2013. Antenatal perineal massage for reducing perineal trauma Cochrane Database of Systematic
Reviews, 4.

Bulchandani, S., Watts, E., Sucharitha, A., Yates, D. \& Ismail, K. 2015. Manual perineal support at the time of childbirth: a systematic review and meta-analysis. Royal College of Obstetricians and Gynaecologists (RCOG), 2015 (122): 1157-1165.

Dahl, W. J., Tandlich, M. A. \& England, J. 2016. Health Benefits of Olive Oil and Olive Extracts. Food Science and Human Nutrition, $16(4)$.

Dahlan, S. 2011. Statistik untuk Kedokteran dan Kesehatan, Jakarta, Salemba Medika.

Elsayed, H. H., Elrahman, M. K. A., Emara, A. H. \& El-Hafez, A. 2015. Compare Effect of Fatty Acid Composition (Olive, Coconut Oil and Butter) on Adipose Liver Tissue, and Serum Lipid Profile in Albino rats. IOSR Journal of Biotechnology and Biochemistry, 1 (3): 28-38.

Endriani, D. S., Rosidi, A. \& Andarsari, W. 2013. Hubungan Umur, Paritas dan Berat Bayi Lahir dengan Kejadian Laserasi Perineum Di Bidan Praktek Swasta Hj. Sri Wahyuni, S.SiT Unimus, 2(1).

Fahami, F., Shokoohi, Z. \& Kianpour., M. 2012. The Effects Of Perineal Management Techniques On Labor Complications. Iran J Nurs Midwifery Res, 17(1): 52-7.

Fatonah, S., Kartika, A. \& Dewi, R. 2013. Efektifitas Penggunaan Virgin Coconut Oil (VCO) secara Topikal untuk Mengatasi Luka Tekan (Dekubitus) Grade I dan II. Jurnal Kesehatan, 4 (1): 264-70.

Fernando, R., Sultan, A., Freeman, R., Williams, A. \& Adams, E. 2015. The Management of Third and Fourth-Degree Perineal Tears. Royal College of Obstetricians and Gynaecologists, 9.

Gamelia, E., Masfiah, S. \& Sari, I. P. 2016. The Determinants Of Husband Behavior In The Care Of Pregnant Women. KEMAS, 12 (1): 68-75.

Garretto, D., Lin, B. B., Syn, H. L., Judge, N., Beckerman, K., Atallah, F., Friedman, A., Brodman, M. \& Bernstein, P. S. 2016. Obesity May Be Protective against Severe Perineal Lacerations. Hindawi Publishing Corporation, 2016.

Gurol-Urganci, I., Cromwell, D., Edozien, L., Mahmood, T., Adams, E., Richmond, D., Templeton, A. \& Meulena, J. V. D. 2013. Third- and Fourth-Degree Perineal Tears Amongprimipar Ous Women in England between 2000 and 2012: time trends and risk factors. BJOG An International Journal of Obstetrics and Gynaecology, 120: 1516-25.

Kalichman, L. 2008. Perineal Massage to Prevent 
Perineal Trauma in Childbirth. IMAJ, 10: 531-533.

Kemenkes. 2012. Survei Demografi dan Kesehatan Indonesia. Jakarta.

Kurniawan, A., Sistiarani, C. \& Hariyadi, B. 2017. Early Detection Of High Risk Pregnancy. KEMAS, 12 (2).

Kurniawan, H. \& Maulina, M. 2015. Hubungan Antara Usia Ibu dan Paritas Dengan Kejadian Plasenta Previa di Rumah Sakit Umum Cut Meutia Kabupaten Aceh Utara Tahun 20122013. Lentera, 15.

Leeman, L., Spearman, M. \& Rogers, R. 2003. Repair of Obstetric Perineal Lacerations. American Family Physician, 68 (8): 1585-1590.

Mahmudah, U., Cahyati, W. H. \& Wahyuningsih, A. S. 2011. Faktor Ibu Dan Bayi Yang Berhubungan Dengan Kejadian Kematian Perinatal. KEMAS, 7 (1): 41-50.

Mukhoirotin \& Khusniah, Z. 2010. Pengaruh Pendampingan Suami Terhadap Kecemasan Ibu Pada Proses Persalinan Kala I Unipdu. Jombang.

Nevin, K. G. \& T.rajamohan. 2008. Influence of virgin coconut oil on blood coagulation factors, lipid levels and LDL oxidation in cholesterol fed Sprague-Dawley rats. e-SPEN, the European e-Journal of Clinical Nutrition and Metabolism, 3 (1).

Nomikos, N., Nomikos, G. N. \& Kores., D. S. 2010. The use of deep friction massage with olive oil as a means of prevention and treatment of sports injuries in ancient times. Arch Med Sci, 6 (5): 642-645.

Prawitasari, E., Yugistyowati, A. \& Sari, D. K. 2015.
Penyebab Terjadinya Ruptur Perineum pada Persalinan Normal di RSUD Muntilan Kabupaten Magelang. Jurnal Ners dan Kebidanan Indonesia, 3 (2): 77-81.

Prismania, P. \& Wagiyo, E. 2013. Hubungan Pendampingan Suami Dengan Tingkat Kecemasan Ibu Primigravida Dalam Menghadapi Proses Persalinan Kala I Di Rumah Bersalin Kota Ungaran. Prosiding Konferensi Nasional PPNI Jawa Tengah.

Puri, R. \& Leppert, P. 2011. Management of perineal and vaginal injuries during childbirth. Wounds International, 2 (2).

Seehusen, D. A. \& Raleigh, M. 2014. Antenatal Perineal Massage to Prevent Birth Trauma. American Family Physician, 89 (5).

Siswosudarmo, R. 2008. Obstetri Fisiologi, Yogyakarta, Pustaka Cendekia.

Stamp, G., Kruzins, G. \& Crowther, C. 2001. Perineal massage in labour and prevention of perineal trauma: randomised controlled trial. $B M J$, BMJ, 322 (7297): 1277-1280.

Vala, G. S. \& Kapadiya, P. K. 2014. Medicinal Benefits of Coconut Oil (A Review paper). International Journal of Life Sciences Research, 2 (4): 124-126.

Verallo, R. V. M., Dillague, K. M. \& Syah-Tjundawan, B. 2008. Novel antibacterial and emollient effects of coconut and virgin olive oils in adult atopic dermatitis. Dermatitis, 19 (6): 308-315.

Zare, O., Pasha, H. \& Faramarzi, M. 2014. Effect of perineal massage on the incidence of episiotomy and perineal laceration. Open Access Health, 6: 10-14. 